Discussion Paper No. 654

CREDIT RATINGS

IN THE JAPANESE BOND MARKET

\author{
Nobuyoshi Yamori \\ Narunto Nishigaki \\ Yoshihiro Asai
}

March 2006

The Institute of Social and Economic Research

Osaka University

6-1 Mihogaoka, Ibaraki, Osaka 567-0047, Japan 


\title{
Credit Ratings in the Japanese Bond Market
}

\author{
Nobuyoshi Yamori*, Nagoya University, ISER Osaka University \\ Narunto Nishigaki, Okayama University \\ and \\ Yoshihiro Asai, Nagoya University
}

\begin{abstract}
Recently, credit ratings have been enhancing the influence on issuers as well as the national economy. This paper explains the historical development and several current features of the Japanese bond market, and discusses why credit ratings gained a significant role in the 1990s. We also present empirical research on credit ratings in the Japanese bond market, and discuss how foreign raters tend to assign lower credit ratings than Japanese ones, but that the relative ratings among raters end up being similar. Finally, we clarify the issues that remained to be solved before credit rating companies can be considered truly reliable.
\end{abstract}

JEL Classification Code: G24

Key Words: Credit Ratings, Bond Market, Japanese Economy, American Raters

*)Corresponding author: Nobuyoshi Yamori, Graduate School of Economics, Nagoya University, Furo-Cho Chikusa-Ku, Nagoya Aichi 464-8601 JAPAN. (tel.)(+81)52-789-4935

$($ fax $)(+81) 52-789-4924$ E-mail: yamori@soec.nagoya-u.ac.jp 


\section{Credit Ratings in the Japanese Bond Market}

\section{Introduction}

Many observers (e.g., Allen and Gale 2000) regard Japan and Germany as bank-centered economies and the United States and United Kingdom as market-centered economics. For example, Figure 1 shows that German firms obtained only $1 \%$ of funds by issuing bonds and Japanese firms obtained 8\% of funds by issuing bonds during the 1997-2001 period. Thus, the bond markets in Japan and Germany have historically played only a marginal role in corporate financing.

\section{Figure 1 About Here}

However, we would like to point out that the Japanese securities market has become important in recent years. Figure 2 focuses on recent developments. During the late 1980s, which was called "the bubble period," "securities excluding stocks" increased because of the increase in the issuance of equity-related bonds, such as convertible bonds and warrant bonds. Furthermore, the financial deregulation and reforms in the late 1990s (e.g., the Japanese Financial Big Bang) have fostered the securities markets, and the share of securities in private firms liabilities has reached around $8 \%{ }^{1}$. Thus, although the absolute level is not yet high if compared with the U.S. figure, it is clear that the bonds market has steadily increased its importance in Japanese corporate financing.

${ }^{1}$ Current Flow of Funds statistics (93SNA Base) are available since 1979. According to the old Flow of Funds statistics (68SNA base), total liabilities of Japanese non-financial corporations at the end of the first quarter of 1965 were 48.3 trillion yen, while "securities excluding stocks" and loans of Japanese non-financial corporations were 1.7 trillion yen and 24.7 trillion yen, respectively. Therefore, securities excluding stocks accounted for only 3.5\% of total liabilities. Their share had decreased to $2.4 \%$ at the end of the first quarter of 1974 . 


\section{Figure 2 About Here}

With the development of the bond market, credit ratings have been enhancing the market's influence on the economy since the 1990s. As explained below, for a long time after the Second World War, only firms that were unlikely to fail (such as utility companies) were allowed to issue bonds. Furthermore, even when issuers went to bankruptcy, all bondholders were protected because bondholder's main bank, which served as a commission bank, usually purchased all bonds at face values. Therefore, bond investors did not have to worry about the probability of issuers' defaults.

This situation changed in the 1990s. After the bond market was deregulated, firms that had not been allowed to issue bonds before could now issue them, and actually did issue. Unfortunately, several bond issuers went into default. In addition, due to weakening solvency, banks could no longer absorb bondholders' losses. Regarding private placement domestic bonds, Muramoto Construction, which failed in 1993, defaulted its bonds for the first time in Japan. Following Muramoto's default, there have been a number of failures which have caused financial losses to bondholders (see Table 1). Furthermore, as shown in the Table, the collection rates were on average lower in Japan than in the United States, where the rates are alleged to be about $40 \%$. Because of these low collection rates, investors evaluated the risk of bonds carefully. Reflecting the needs of investors, credit ratings began to play an important role in the Japanese bond market.

\section{Table 1 About Here}

This paper aims to explain the current role and issues of credit ratings in the Japanese bond market. The paper is organized as follows. In section II, we explain the historical development of the Japanese bond market and several features of the market up until the 1980s, during which credit ratings were given only a minor role. In section III, we discuss why credit ratings played a significant role in the 1990s. In addition, we provide two episodes that show the impact of credit ratings on the nation and private firms. Although S\&P and Moody's are important raters in Japan, there are three Japanese raters which are very different from U.S. raters in terms of rating policy. Therefore, to enable international readers to understand the difference between Japanese and U.S. 
raters, we provide an explanation of the important features of Japanese credit raters in Section IV. In Section V, we present findings from empirical research we conducted on credit ratings in the Japanese bond market. We found that foreign raters tended to assign lower credit ratings than Japanese ones, but that the relative ratings among raters became similar. Section VI concludes the paper.

\section{Brief History of the Spread of Credit Ratings in Japan}

Until the Great Depression in the 1930s, most debentures in the Japanese bond market were issued with no collaterals except foreign bonds issued by Japanese corporations. During this period, conflicts between investors and defaulted issuers were incessant, and financial institutions that undertook defaulted bonds were blamed for being remiss. Therefore, the default disposal procedure in which undertakers ultimately purchased defaulted bonds in place of issuers became a normal practice before the 1930s.

However, the sharp increase of defaults after 1930 made it difficult for undertakers to take over debts. As a result, the commercial law was revised in 1938, and the so-called Rule of Compulsory Collateral was established. The Rule required corporations to use their lands or buildings as collaterals whenever they issued bonds.

After World War II, the Japanese Ministry of Finance (MOF) and the Bank of Japan (BOJ) strengthened investor protection through the establishment of the Qualification Standard for Bond Issuing. This Standard excluded unsuitable issuers from the bond market. To begin with, bond-issuing-suitable corporations were screened through several financial indicators such as the amount of capital stock, net assets and capital ratio. Next, selected qualified corporations were rated into four ranks (i.e., AA, A, BB and B), and the amounts that each company were allowed to issue were dependent on its rank. This ranking system is different from the American type of credit rating system. Japanese ranking was used to select who could issue bonds, while the American type of rating was used to estimate the default risks of bonds.

Bond issuing was not attractive for corporations that had high creditworthiness, because all issuers were charged at almost the same interest rates and could not issue what they wanted regardless of their creditworthiness. Because of this, in the 1970s many Japanese corporations 
began to issue foreign bonds in the New York, London, and Swiss markets. This trend forced the MOF and the BOJ to consider how to avert the hollowing of the domestic market.

In October 1977, the Securities and Exchange Council, which was an advisory committee of the MOF, published “A Report on What the Japanese Bond Market Should Be”, in which the Council advanced that the MOF should liberalize corporate bonds being issued in Japan. Additionally, the Council suggested the need to introduce an American type of rating system into Japan, where outsider institutions without interests for issuers could estimate the abilities of bond issuers to redeem those bonds and inform investors of these results. Furthermore, in the report, the Council proposed the approval of debentures with no collaterals and the establishment of investors' self-responsibilities principle. However, it took a substantial amount of time for the MOF to implement these proposals for bond market reform.

In January 1984, the MOF and financial institutions together organized the Workshop of Debenture Issues, and the Workshop began discussing what roles the American type of raters had played. The Workshop then published their assessment in the report of the US-Japan Dollar-Yen Committee. They made three crucial points in their assessment: (1) that plural rating agencies should be established, (2) the independence of these agencies should be assured, and (3) both issuers and investors should be required to pay rating charges.

It was in 1985 that credit rating agencies as independent organizations began to operate in Japan. During this year, Moody’s and S\&P opened their offices in Tokyo, and two domestic raters, the Japan Credit Rating Agency (JCR) and Nippon Investors Service (NIS), were established. In addition, the Japan Bonds Research Institute (JBRI) was incorporated in the same year. In July 1987, the MOF permitted Moody's, S\&P, Fitch Investors Service, JCR, JBRI and NIS to assign credit ratings with fees. They were called the Designated Rating Agencies. In October 1992, the MOF added Duff \& Phelps, ICBA Ltd., and Thomson Bank Watching to the Designated Rating Agencies.

However, in the first decade of the raters' history in Japan, the Qualification Standard for bond issuing was still in effect. In February 1987, the MOF added a new rating qualification (i.e., "above AA" or "above A with more than 55 billion yen of net assets") to the traditional numerical standards (e.g., 300 billion in net assets and more than $30 \%$ of the equity ratio). A corporation satisfying either the new or traditional standards was admitted to issue bonds. However in June 
1990, the numerical standards were abolished, and the rating standard was eased from "above BBB with collaterals” or “above A without collaterals,” to "BB with collateral” or "BBB without collaterals” in April 1993. Finally, the Qualification Standard was completely abolished in January 1996. That is, all firms were allowed to issue bonds if the bonds could be sold, and the interest rates were made dependent on the issuers' financial conditions (Yamasawa 2003).

The abolition of requirements for issuing bonds itself caused several transformations in the Japanese bond markets. Kurosawa (1999) pointed out the following two transformations. First, a firm even in the worst financial situation in principle could issue bonds by paying high interest rates reflecting the risks. Therefore, investors needed to obtain information about the size of risks of issuers. However, investors and analysts found it difficult to obtain relevant information for investment in securities because corporate disclosure was not sufficient at the time when the bond market deregulation was carried out.

Another transformation was that Japanese corporations were now able to issue debentures without obtaining credit ratings. Previously the issuers had been obliged to obtain ratings from one of the Designated Rating Agencies in the case of straight bonds, and from two or more Designated Rating Agencies in the case of CBs. Abolition of this obligation encouraged competition among rating agencies in the markets. As a result, in April 1998, JBRI merged with NIS and restarted as R\&I. In addition, the abolition also set off full-scale activities of Moody's and S\&P in Japan.

After the overall abolition of the Qualification Standard, the amount of issuing bonds, particularly by high rated corporations, increased because corporations were now able to finance at low costs suitable to their creditworthiness. Figure 3 shows the recent development of straight bond markets in Japan. It is apparent that the amount issued sharply increased in the 1990s. R\&I (1998) stated "the expansion of the corporate bond market has compensated for the depression of the indirect financial system in Japan to some extent”(p.59).

Figure 3 About Here

\section{Epoch-making Events Regarding Credit Ratings in Japan}




\section{III-1. Downgrading and Financial Crisis in 1997}

In the late 1990s, large-scale bankruptcies of city bank, securities companies, life and non-life insurance companies, construction and major distribution companies occurred in quick succession. The worst year of this financial crisis was $1997^{2}$. In November 1997, several large financial institutions went bankrupt. Sanyo Securities, one of the backbone general securities companies in Japan, collapsed on November 3rd. On November 17th, Hokkaido-Takushoku Bank, one of the Japanese city banks, transferred its management right to Hokuyo Bank and in effect went bankrupt. A week later, on November 24th, Yamaichi Securities, one of the Big 4 securities companies in Japan, announced its decision to voluntarily close its business.

There was criticism that credit ratings intensified the crisis. On November 21st, Moody's announced it was downgrading Yamaichi Securities' unsecured CB’s rating from Baa3 to Ba3. On the other hand, despite maintaining Yamaichi's rating at BBB-, S\&P announced it was putting Yamaichi on negative lists and would possibly downgrade Yamaichi's rating. Moody's gave the following reasons for downgrading Yamaichi: 1) Yamaichi had lost market trust, 2) it had declined in financing ability, and 3) its capital position had become fragile. The day after this announcement, although the chief of MOF's Bureau of Securities announced that Yamaichi was not insolvent despite more than 200 billion yen of off-balance-sheet liabilities, participants in the inter-bank markets took the downgrade by Moody's seriously, and stopped lending to Yamaichi entirely. Two days later, Yamaichi's board of directors unanimously decided to close their business.

\section{III-2. Downgrading of Japanese Government Bonds}

Credit ratings on Japanese government bonds (JGBs) are important issues for Japan, because the total debt held by the Japanese government amounted to 751 trillion yen as of March 2005. If

${ }^{2}$ However, a careful investigation finds that fundamental changes had already realized before the crisis. First, yields in Japanese bank debentures, which used to be the same among all banks, started to depend on issuing banks. Second, the number of bankruptcies steadily increased. Third, in September 1997, a main bank of Yaohan Japan rejected to take up Yaohan's CBs after its bankruptcy. It was the first default that occurred in Japanese publicly-issued domestic bond market since the end of World War II. 
the interest rates of JGBs increase by $1 \%$ due to the downgrading of credit ratings, the government will have to pay an additional 7.5 trillion yen, which is one-sixth of the annual tax revenue of the government.

In April 1998, Moody's changed the yen-denominated JGBs ratings from Aaa stable to Aaa negative. Moody's simply explained that uncertainty had increased as to whether it would be possible for the Government to achieve its central aims, economic growth and fiscal improvement. In June 1998, Moody’s released a detailed report analyzing the Japanese economy. This report emphasized three factors destabilizing the Japanese economy: fiscal deficits, surplus in the balance of payments, and deflationary pressure. Eventually, Moody's downgraded yen-denominated Japanese Government Bonds to Aa1 in November 1998, to A2 in September 2000, to A3 in December 2001, and A2 in May 2002. Similarly, S\&P downgraded yen-denominated JGBs from AAA to AA+ in February 2001, to AA in November 2001, and to AA- in April 2002. Fitch also downgraded yen-denominated JGBs from AAA to AA+ in June 2000, to AA in November 2001, and to AA- in November 2002.

As of August 2005, yen-denominated JGBs have been assigned A2 ratings by Moody’s. Among the G-7 countries, Japan has the lowest ratings and the second lowest is Italy with Aa2, which is 3 notches higher than A2. Other G-7 countries have AAA grade ratings. Countries that have been given the A2 grade include Israel, South Africa, Poland, Mauritius, Kuwait and Latvia. It is true that the Japanese government is having financial difficulties. Its tax revenue only covers approximately half of its expenditures, and about one-fifth of these expenditures consist of interest payments for JGBs issued in the past. In addition, if interest rates increase, then the government will be unable to pay the interest. Furthermore, to judge the creditworthiness of a country, the independence of its central bank is an important factor, because the expected inflation rate affects sovereign risks. Despite the new Bank of Japan Law, Japan is still regarded as not having a completely independent central bank (Iwasaki 2004).

However, the MOF was not satisfied with the decision by Moody's and claimed that "considering the strong fundamentals of the Japanese economy, the current ratings of JGBs are already too low and any further downgrading is unwarranted. Your explanations regarding rating decisions are mostly subjective in nature and lack objective criteria, which invite questions about 
the reliability of rating itself" ${ }^{3}$.

Unlike with private corporations, it is difficult for sovereign ratings to be statistically confirmed through default experiences. Kurosawa (1999) indicated that compared with the credit ratings of private firms, the correlation between the sovereign ratings given by Moody's and those by S\&P were lower. In addition, in the case of the monetary crisis in Asia in 1997, raters changed the sovereign ratings of Asian countries four or five times within one year. Ferri et al. (1999) insisted that it was credit rating agencies that aggravated the Asian monetary crisis.

\section{Japanese Rating Agencies}

\section{IV-1. General Characteristics of Japanese Rating Agencies}

As we mentioned above, in 1984 the Workshop of Debenture Issues pointed out that independent rating agencies were necessary and that both investors and issuers should pay rating costs. According to the "independence" criterion, credit rating agencies are required not to have any capital and creditor-debtor relations with financial institutions that have interests in bonds issuing or bond-related administrations. For example, if a securities company dealing with bond issuing was a major stockholder of a rating agency, that agency might be lenient in rating bond issuers who are clients of that securities company.

Despite the Workshop's proposal, the MOF decided in 1985 that credit rating agencies were required to be capitalized by financial intermediaries and securities firms because the experiences of bankers in terms of screening long-term-lending and of analysts in securities firms in terms of underwriting bonds were necessary in order to assign appropriate credit ratings to long-term bonds. The MOF maintained that conflict of interest problems were avoidable by setting a subscription limit per investor within $5 \%$ of the entire capital. Although the MOF's decision was understandable given the circumstances of the 1980s, the capital structure of Japanese rating agencies has not been improving since then. As a result, more than half of the stocks of JCR and more than $40 \%$ of R\&I are still occupied with financial institutions, including banks, securities companies and insurance companies. As the U.S. Securities and Exchange Commission has not accepted the Japanese MOF's decision, JCR and R\&I cannot sell their rating information in the

${ }^{3}$ See http://www.mof.go.jp/jgb.htm . 
United States.

The issue of "who pays rating costs" is also important, because a rating agency could rate so as to give the payer an advantage. If only investors were to pay the costs, the ratings could tend to be stricter. However if only issuers pay the costs, the rating could be prone to be favorable to the issuers, who wish to finance at lower interest rates. Accordingly, as in the U.S., the Workshop of Debenture Issues thought that both investors and issuers should pay the costs to make the ratings fair. However, at that time in Japan, several institutional investors insisted that they had disagreed about paying for rating information to rating agencies because firms that were in bad financial condition were not permitted to issue debentures, and because credit ratings at that time had no information value. Consequently, the MOF decided that only issuers would pay rating costs for the time being, and investors would be required to pay the costs after the necessary conditions had been arranged. Although more than twenty years have passed, the system still remains unchanged in 2005.

Additionally, it is notable that there are two large differences between Japanese agencies and U.S. agencies in terms of rating operation. First, agencies in the United States value disclosed information such as financial statements, while Japanese agencies tend to put a high value on non-public information acquired through private interactions with firms. It is generally true that the financial soundness of Japanese corporations presented through disclosed data such as ROE, the equity ratio and liquidity ratio is inferior to that of U.S. corporations. Therefore, the ratings of U.S. agencies that put a high value on financial statements necessarily tend to be stricter for Japanese firms. Japanese rating agencies consider "qualitative information" as well as financial statements. For example, they think that the cross-holdings of equities, main-banks relations, keiretsu affiliations, a convention of priority payments in debenture or the government's back-ups are not shown in the balance sheet but enhance the firm's creditworthiness. It is quite natural that the ratings of Japanese raters which consider these factors are higher than those of American raters ${ }^{4}$.

${ }^{4}$ However, there is a counter-evidence to this argument. Shin and Moore (2003) found that despite clear difference in rating between Japanese raters (JCR and R\&I) and U.S. raters (Moody's and S\&P), the rank correlations were relatively high. And they estimated ordered probit models to test whether each of the four agencies considered keiretsu affiliation. For non-financial 
Second, Japanese agencies are slower to downgrade firms than U.S. agencies ${ }^{5}$. Foreign raters anticipate the outcome of the event and change ratings in advance, while Japanese raters keep ratings unchanged until the actual effect of the event emerges. When a situation is deteriorating, Japanese raters tend to be slow to downgrade. Therefore, Japanese raters assigned inevitably higher rates than U.S. raters during the burst of the bubble period.

In the following sections, because Moody's and S\&P are well known to international readers, we would like to give a detailed explanation of Japanese credit rating agencies.

\section{IV-2. Japan Credit Rating Agency (JCR)}

Japan Credit Rating Agency (JCR) was established in April 1985 and capitalized by life and non-life insurance companies, trust banks, regional banks and long-term credit banks. In November 1985, it began to publish "JCR Reports", and in the next year, it started pay-rating on yen-denominated foreign bonds.

At the end of FY 2003, the ratings of JCR covered the $64.4 \%$ (590 firms) of Japanese firms which had obtained credit ratings. Its covering rates were especially high in the financial business $(69.8 \%)$, distribution industry $(71.9 \%)$ and non-manufacturing industry $(73.9 \%)^{6}$. JCR has more actively rated foreign firms than R\&I. Therefore, it has promoted business tie-ups with foreign rating agencies such as the SCI in Korea (August 2000) and the DCR-VIS in Pakistan (January 2001).

JCR does not execute non-requested ratings as a rule. JCR is considered superior to U.S. rating agencies in that JCR publishes their reports in Japanese as well as in English, and its analysts

firms, keiretsu affiliation negatively affected its rating for one U.S. agency and one Japanese agency. And for financial firms, both U.S. agencies assessed keiretsu affiliation positively, while Japanese agencies did not.

${ }^{5}$ Of course, even U.S. raters are often criticized because a firm that was rated above BBB went bankrupted. Ratings are less prompt in reflecting new information than other market variables such as stock prices. For example, Bongini et al. (2002) supported previous findings that credit rating agencies have been slow in adjusting their ratings for the East Asian banks during the onset of the East Asian crisis.

${ }^{6}$ See http://www.jcr.co.jp/information/puroh.htm. 
have constructed better and more loyal relations with Japanese firms and institutional investors than U.S. agencies through closer contacts with them. Moreover, JCR examines and monitors Japanese firms more carefully and cooperatively than U.S. agencies, and tries to describe Japanese firms more comprehensively than foreign analysts (Fight 2003).

However, this agency has several faults. In particular, we cannot disregard the fact that it is capitalized by about one-hundred financial institutions. Formerly JCR employed many analysts coming from these institutions, and it was reasonably wondered whether they could properly rate the institutions they had formerly been employed by. Of course JCR now employs many analysts who have no relation with the financial institutions, but this independence problem still remains. In addition, JCR was criticized for its rating ability because it assigned BBB to Mycal Co., a major retailer in Japan, in October 2000, but it went bankrupt in September 2001.

\section{IV-3. Rating \& Investment Information (R\&I)}

Rating \& Investment Information (R\&I) originates from the Institute of Public and Corporate Bonds established within Nihon Keizai Shinbun, Inc. (a major business newspaper) in March 1975. In 1978, the Institute published the first ratings of listed CBs in the newspaper, and tentatively started rating new CBs. The following year, the rating operations were transferred from an in-house sector of the newspaper company to a private organization, Japan Bonds Research Institute (JBRI). JBRI was incorporated in April 1985 and started new rating services such as shogun bond ratings. Another Japanese rating agency, Nippon Investors Service, Inc. (NIS) was born that same April. This agency was capitalized by the Industrial Bank of Japan, city banks, trust banks, regional banks, life and non-life insurance companies, and a think tank established by a securities company and a press company. NIS published the first issue of the NIS Rating Information (in Japanese) in February 1986.

In April 1998, R\&I was established through the merger of JBRI and NIS ${ }^{7}$. Nihon Keizai Shinbun, Inc. and its subsidiaries hold fifty-six percent of the stocks of R\&I, and various financial institutions hold the rest. Therefore, this agency has the same independence problem as JCR due to the structure of its stockholders.

At the end of October 2002, R\&I rated 705 firms. It has also promoted business tie-ups with

${ }^{7}$ See http://www.r-i.co.jp/eng/company/history.html. 
foreign rating agencies such as Fitch Ratings and NICS (an investment information company in Korea). Furthermore, R\&I has been urged to extend its rating services to academic institutions, local governments, and special public corporations.

\section{IV-4. Mikuni \& Co., Ltd.}

Unlike JCR and R\&I, Mikuni \& Co., Ltd. is a rating agency without the designation of the MOF. It was established in 1975, and began offering financial analyses. It began issuing credit ratings in 1983. In the beginning, its main business was supplying foreign investors with information about Japanese firms issuing bonds in foreign countries. Now Mikuni's credit ratings cover 1500 Japanese firms. ${ }^{8}$ This number is far above those of other rating agencies in Japan.

The distinguishing characteristic of Mikuni is that it has no business tie-up with any outsiders, and is completely free from any direction from and regulation by the government. One of Mikuni's corporate philosophies is to keep itself independent from any companies, bond issuers, financial institutions, brokers and government authorities because such independence enables it to form and express its opinions freely and objectively ${ }^{9}$.

Other characteristics of Mikuni's credit ratings are as follows. In contrast to designated agencies (i.e., JCR and R\&I), Mikuni earns rating charges only from investors, not from issuers, and utilizes only disclosed information. In addition, it doesn't use the sovereign ratings of foreign firms to estimate each debenture. In other words, in terms of the usage of sovereign information, Mikuni is not only different from Japanese rating agencies, but from U.S. agencies, and thus Mikuni does not change ratings easily when unexpected events such as natural disasters or acts of terrorism occur.

Mikuni \& Co., Ltd. is also well known as the strictest rater of Japanese firms. For example, it was Mikuni that first assigned different ratings among long-term credit banks in Japan. At the end of October 2003, the ratio of investment grade to speculative grade was 1 to 2, which was far stricter than those of Moody's and S\&P at the same point in time.

\footnotetext{
${ }^{8}$ See http://www.mikuni-rating.co.jp/jp/jpcompany/framepagecompany.html.

${ }^{9}$ See http://www.mikuni-rating.co.jp/eng/encompany/enframepagecompany.html .
} 


\section{An Empirical Investigation of Japanese Credit Ratings}

\section{V-1. Overview of Straight Bond Market}

As discussed in the Introduction, bond issuance is not a primary source of outside funds for average Japanese firms. It is apparent that small firms cannot issue bonds because of information problems and large fixed expenditures. However, owing to deregulation, it is notable that large firms have increased their dependency on bonds.

In addition to the increase in the volume of bond issuance, there has been an important change. Namely, various kinds of firms now issue bonds. During the regulated period, the share of utilities companies in the bond issue market was very large. In the 1990s, as shown in Figure 4, the importance of utility companies as bond issuers decreased because their demand for funds significantly decreased.

Along with these developments, credit ratings and rating agencies are playing an increasingly important role in Japanese financial systems. We will investigate the actual credit rating practices in Japan and answer the following questions: (1) Raters shares: How has the share of each rating agency changed over times? (2) Multi-ratings: What kind of rater combination is popular? Who obtains multiple ratings? (3) Differences in ratings among raters: Are there any differences in ratings among raters? How have the differences changed over time?

\section{Figure 4 About Here}

\section{V-2. Data}

Here, we collected the ratings assigned at the time that new publicly-offered straight corporate bonds were issued. We obtained the data for FY 1993 and FY 1996 from Koshasai Nenkan (Public Bond Yearbook) and for FY 2000 and FY 2004 from the website of Shokengyo Kyoukai (Japan Securities Dealers Association, or JSDA). Although some companies issued corporate bonds several times in one year, we counted each as a different issuance. Anecdotally, we attempted to analyze credit ratings in the 1980 s, but there was no available data on the ratings of corporate debts in the $1980 \mathrm{~s}^{10}$.

10 This is an indicator that credit ratings were not important in the $1980 \mathrm{~s}$. 


\section{V-3. Results}

\section{V-3-1 Who gains a share in the rating market?}

There were five qualified rating agencies in Japan before 1998 and four rating agencies after 1998, when JBRI and NIS were merged into R\&I ${ }^{11}$.

Firms can issue bonds with obtaining credit ratings from one rater ${ }^{12}$. However in practice, firms often obtained credit ratings from two or more credit rating companies. Table 2 shows the distribution of multiple ratings regarding straight bond issuance.

In 1993, more than $60 \%$ of issuances were with single credit ratings. That ratio decreased to $40 \%$ in 1996 . We should note that the figures in 2000 and in 1996 were not directly comparable, because of the merger of JBRI and NIS. If a firm obtained credit ratings from JBRI and NIS in 1996 and from R\&I in 2000, the firm was classified into the multi-rater category in 1996 and the single-rater category in 2000. The ratio of single-rater categories for 2000 and 2004 are almost the same (i.e., around 55\%). Thus, currently, approximately half of issuers obtain credit ratings from two or more raters. However, it is also notable that very few companies obtain credit ratings from all four raters. In other words, firms choose their raters.

\section{Table 2 About Here}

Table 3 shows which raters were chosen by issuers. In 1993, 56 firms chose JBRI as a rater. Only 10 companies obtained ratings from JCR in 1993. In 1996, Moody's was the top among the

11 Although Fitch and Mikuni also operate in Japan, our data source does not contain any information about ratings of these raters.

12 Strictly speaking, a firm now can issue bonds without credit ratings. However, our data source does not contain bonds issuance without credit ratings. For example, as JSDA reported that 307 straight corporate bonds were issued in FY 2004 and our data source identified 297 bonds, at most 10 bonds were issued without ratings. Based on the similar calculations, we find that 0 for 1993 , 7 for 1996, and 17 for 2000 were issued without ratings. 
five raters, followed by JBRI. In 2000, R\&I was the top, followed by JCR. The number of bonds with ratings from Moody's significantly decreased. In 2004, R\&I assigned credit ratings to 202 issuers. This means that $73.4 \%$ of issuers obtained rating from R\&I. In contrast, American raters lost their market shares in 2004. Moody's covered 51.8\% of issuers in 1996, while it covered only $16.8 \%$ in 2004 . Thus, it is apparent that Japanese rating firms increased their influence in Japanese financial markets.

\section{Table 3 About Here}

\section{V-3-2 Who jointly assigns ratings?}

As shown in Table 2, about half of issuers obtained credit ratings from two or more credit raters in 2004. It is interesting to investigate what kind of combinations were popular and how those combinations changed over time. For example, if American raters' ratings are valuable for international investors and Japanese raters' ratings are valuable for domestic investors, firms that want to sell bonds both in international and domestic markets need to obtain credit ratings from both American and Japanese raters.

In 1993 and 1996, as there were five raters, there were 10 two-rater combinations ${ }^{13}$. In 2000 and 2004, there were six combinations. Table 4 shows the results for 1993 and 1996. The combination between JBRI and Moody's (MDY) was the most popular in 1993 and 1996, followed by the combination between NIS and Moody's. Table 5 shows the results for 2000 and 2004. In contrast to the previous years, R\&I-JCR combination was the most prevalent in 2000 and 2004. To put it another way, a Japanese-American combination was popular before 2000, but a Japanese-Japanese combination became popular after 2000 (see Table 6). Thus, this is consistent with the argument that the roles of Japanese rating agencies become more and more important in the 2000s.

\section{Table 4 About Here}

\footnotetext{
13 Regarding triple ratings (such as JCR, Moody's and S\&P), we identify three two-rater combinations; JCR-Moody's, Moody's-S\&P, and JCR-S\&P.
} 


\section{Table 5 About Here}

Table 6 About Here

\section{V-3-3 Who obtains multiple ratings?}

There is a possibility that multiple ratings may be effective in mitigating information asymmetries. If so, a firm that suffers from larger asymmetric information problems will more likely obtain multiple ratings. However, multiple ratings may not make any difference, or make matters even worse because firms have to pay to obtain multiple ratings.

We investigated what factors encouraged issuers to obtain multiple ratings by using the 2004 data. More concretely, we tested whether the amount issued, maturity, and interest rates were related with the number of ratings. For example, when a firm issued larger amount of corporate bonds and increased the leverage ratio, information asymmetries became worse. Such an issuer has an incentive to obtain multiple ratings to reduce information asymmetries.

Table 7 shows how the number of credit ratings is related to the amount issued, maturity and interest rate. First, when a firm issues bonds that are worth a high amount, the firm tends to obtain two or more ratings. Second, the average maturity for bonds with one credit rating is 7.29 years, while it is 8.17 years for bonds with three credit ratings. Although bonds with two credit ratings have a longer maturity period than those with three ratings, a firm that issues bonds with longer maturity tends to obtain more credit ratings. Finally, there is no apparent relationship between the number of raters and interest rates. As multiple ratings alleviate the information problems, interest rates obtained by using multiple ratings would be lower than those obtained without multiple ratings. However, if the firms that have large asymmetric information problems choose multiple ratings, then the interest rates of bonds with multiple ratings will tend to be high. Therefore, these cross-interactions may make the relationship between the number of raters and interest rates ambiguous.

These results are consistent with the hypothesis that credit ratings are used to mitigate information problems. Of course, it should be noted that our results are tentative, because the data we used here was only for 2004. In addition, we need to conduct a more formal test in which several factors are controlled to reach a definitive conclusion. 


\section{Table 7 About Here}

\section{V-3-4 How do credit raters assign different ratings?}

As Shin and Moore (2003) pointed out, credit rating standards are different among raters. Here, we will first investigate how different the raters's standards are. Following Morgan (2002), who assigned each credit rating a numerical number, such as $\mathrm{AAA}=1, \mathrm{AA}+($ or $\mathrm{Aa} 1)=2$ and $\mathrm{AA}$ (or Aa2) $=3$, we calculated the average ratings for each rater.

The results are shown in Table 8 . In 1993, the average S\&P rating was 1.88. As this means that most companies had AAA or AA+ ratings from S\&P, S\&P rated only highly solvent companies. The averages of Moody's and JCR were 5.19 and 6.13, however, suggesting that they rated companies having relatively lower creditworthiness, if the rating standards were the same among these raters. While the difference in the average ratings between rating companies was relatively large in 1993, the difference became smaller in 2000 and 2004. Namely, the average ratings ranged from 4.35 to 5.42 in 2000 and from 5.14 to 5.52 in 2004.

\section{Table 8 About Here}

Following the argument of Morgan (2002), the convergence of credit ratings is a signal of an improvement in the information problems. Thus, due to the disclosure and accounting reforms enacted since the late 1990s, we can tentatively conclude that credit rating companies can evaluate the creditworthiness of issuers much more precisely than before.

However, an important question must be posed. Are the criteria of rating companies really the same? For example, Tokyo Electric Power Co. obtained a rating of AAA from JCR, AA+ from R\&I, and AA-(Aa3) from S\&P and Moody's in 2004. Similarly, JFE (a major steel maker) obtained a rating of A+ from JCR, A- from R\&I, and BBB- from Moody's in 2004. Thus, there was a difference of three notches for Tokyo Electric Power and five notches for JFE. This suggests that bond rating agencies still have different criteria.

To consider the difference in criteria, we will focus on firms that obtained more than two credit ratings (which we call "overlapped firms" below). As explained above, there were ten 
combinations of raters for 1993 and 1996 and six combinations for 2000 and 2004. However, several combinations had no overlapped firms. For example, there were no firms that obtained credit ratings from both JCR and S\&P in 1993.

First, we calculated the average credit ratings for overlapped firms regarding each combination of raters. The results are shown in Table 9. For example, in terms of the combination between JBRI and NIS, there were 12 overlapped firms in 1993. We found that the average ratings of JBRI and NIS for these 12 firms were 2.00 and 1.67, respectively. The results show that there are significant difference among Japanese raters and American raters. For example, there was a difference of 2.2 notches in 1993 and 2.9 notches in 1996 between JBRI and Moody's. More apparently, there was a difference of 2.8 notches in 1993 and 3.5 notches in 1996 between NIS and Moody's. Even in 2004, there were large differences between Japanese and American raters. Specifically, there were 3.4 notches difference in 2004 between JCR and Moody's.

In sum, Japanese raters assigned more favorable credit ratings than American raters. As the difference is about three notches, a firm with a credit rating of $A+$ from a Japanese rater will obtain a credit rating of $\mathrm{BBB}+$ from American raters. The bond market reflects this difference. For example, as shown in Figure 5, interest rates of bonds with a BBB rating from S\&P and Moody's are almost the same as those with an A from R\&I and JCR.

\section{Table 9 About Here}

\section{Figure 5 About Here}

It could be argued that absolute differences among raters may not be important, because we can adjust for the differences. However, if a Japanese rater regards Firm A as more solvent than Firm B, and a U.S. rater regards Firm A as less solvent than Firm B, market participants will find it difficult to evaluate relative creditworthiness between these firms. If raters are similar in terms of evaluating relative creditworthiness among firms, the correlation coefficients of ratings should be high. Therefore, we calculated the correlation coefficients.

Table 10 shows that simple correlation coefficients regarding overlapped firms have become larger over time. The correlation coefficients between JBRI and NIS were 0.934 in 1993 and 0.986 in 1996 . This suggests that these two Japanese raters used very similar rating criteria. The 
coefficients between S\&P and Moody' were 0.701 in 1993 and 0.718 in 1996. This suggests that American raters used slightly different rating criteria. Although the correlation coefficient between JBRI and Moody’s was very high (i.e., 0.972) in 1993, the correlation coefficients between American raters and Japanese raters were generally small. Namely, the correlation coefficient between JBRI and S\&P was 0.441 in 1993 and that between NIS and Moody's was 0.673 in 1993 . The results for 1996 were the same as for 1993. The correlation coefficient between JBRI and NIS was very high (0.986), and the correlation coefficients between American raters and Japanese raters ranged from 0.718 to 0.912 . However, JCR was an exception. Judging from the fact that JCR ratings were not closely related with the other raters' ratings, JCR used a different criteria.

\section{Table 10 About Here}

In 2000, the correlation coefficients of JCR with the other raters became higher than before. The lowest value was found in terms of the combination of S\&P and Moody's. This suggests that there were strong disagreements about Japanese firms' creditworthiness between American raters. In 2004, all correlation coefficients in 2004 except between JCR and Moody's were close to one. In particular, the correlation coefficients between Japanese raters (i.e., JCR and R\&I) and those between American raters (i.e., Moody's and S\&P) were very high. That is, these results in Table 10 are consistent with the argument that corporate disclosure reforms in the late 1990s have brought more accurate ratings, but there are some differences in rating criteria between Japanese and American raters.

\section{Concluding Remarks}

In this paper, we pointed out the increasing role that credit ratings are playing in Japan. However, there are a lot of problems with ratings that remain to be solved. One issue concerns American raters in Japan. In Japan, American raters are strongly criticized because people suspect that Moody's and S\&P assign inappropriately low ratings to Japanese issuers. The actual default rates in the Japanese market do not seem to support these low ratings. Annual data 
released by Moody's and S\&P show that their ratings are closely related with actual default ratios, but this only means that their ratings of U.S. companies are closely related with actual default ratios, and does not mean that their ratings of Japanese companies are also closely related with actual default ratios.

Japanese managers are often unsatisfied with the reasons given for downgrading by American raters, because they feel that American raters do not understand business practices in Japan. For example, according to Fight (2003), Moody's degraded the rating of Toyota Motor Corporation from AAA to Aa1 in 1998 on the grounds that competition in the global automobile market is intensifying, and Toyota's competitiveness has weakened due to its practice of giving workers lifetime employment. In refuting Moody's, Mr. Okuda, the CEO of Toyota Motor Co., argued that the lifetime employment system was not a burden for Toyota because it had adopted a flexible employment structure. Eventually, Moody’s upgraded Toyota's rating from Aa1 to AAA in 2003.

Furthermore, Fight (2003) pointed out the fact that none of twenty-five Japanese corporations that Moody's assigned speculative grades to before 1998 had defaulted as of October 2003, while the probability that firms rated Ba by Moody's would default within five years was 11.4 per cent. He pointed out that Moody's might have disregarded specific factors in the Japanese market (e.g., mainbank relations) which lower default rates ${ }^{14}$.

There are also deep-rooted complaints against “unrequested ratings" by U.S. agencies in the Japanese bond market. In terms of unrequested ratings, there is a slight difference between S\&P and Moody’s. S\&P clearly distinguishes "requested" and "unrequested" ratings for investors because investors recognize that unrequested ratings rely on less information or less reliable information than requested ratings. In contrast, Moody's insists that they are able to maintain the same quality for unrequested ratings as requested ones, so Moody's doesn't disclose the distinction at all.

Although there is considerable evidence that American raters are not always right, there are also serious problems with Japanese raters. As mentioned in Section IV, except for Mikuni \& Co., Japanese credit rating agencies are not independent from issuers and financial institutions. Namely, JCR and R\&I are still substantially capitalized by financial institutions. In addition,

${ }^{14}$ However, as he noted, such factors would be going to weaken due to the deregulations and globalization. 
these Japanese raters earn rating charges only from issuers. In other words, investors are not the customers of these raters. In fact, except for Mikuni, Japanese raters tend to assign better ratings to Japanese issuers than American raters. It is necessary to investigate whether the capital structure and business practices of Japanese raters distort their rating decisions.

Finally, we should point out that Japanese investors may not fully understand the meaning of rating grades. The Japanese mass media often state that a rating below $\mathrm{BB}+$ is considered an “inadequate to invest" grade, not a "speculative grade”, and Japanese investors also accept this interpretation. Therefore, in the Japanese market, once a firm is rated below $\mathrm{BB}+$, the firm can no longer obtain necessary funds. However, “a speculative grade” doesn't mean that people shouldn't purchase the firms' bonds, but just means that there are relatively high risks to purchasing the bonds and a high expected return. Therefore, Japanese investors need to be educated on how to use credit ratings properly.

Thus, although credit ratings play a very important role in Japan, much remains to be done before credit ratings can be considered reliable and before they can be properly used in Japan. 


\section{$<$ References $>$}

Allen, F., and D. Gale, 2000, Comparing Financial Systems, Cambridge, Mass. ; MIT Press.

Bongini, P., Laeven, L., Majnoni, G., 2002. How good is the Market at Assessing Bank Fragility? : A Horse Race between Different Indicators. Journal of Banking \& Finance 26, 1011--28.

Bremer, M., Pettway, R. H., 2002. Information and the Market's Perceptions of Japanese Bank Risk: Regulation, Environment, and Disclosure. Pacific Basin Finance Journal 10(2), 119--39.

Ferri, G., Lui, G., Stiglitz, J.E., 1999. The Procyclical Role of Rating Agencies: Evidence from the East Asian Crisis. Economic Notes by Banca Monte dei Paschi di Siena SpA 28(3), $335--55$.

Fight, A., 2003. The Rating Game, New Material prepared for Japanese edition, Springer-Verlag Tokyo, (the English Language edition by John Wiley \& Sons, Ltd. 2001).

Institute for Posts and Telecommunications Policy of Ministry of Internal Affairs and Communications, Research Report on Security Market and Security Investments, March 2003(in Japanese).

Iwasaki, H., 2004. Reading the "Rating” Market: Who Will Benefit from It (in Japanese), Kobunsha Co.

Kurosawa, Y., 1999. Economics of Rating (in Japanese). PHP Research Institute Inc.

Morgan, D. P., 2002. Rating Banks: Risk and Uncertainty in an Opaque Industry. American Economic Review 92(4), 874--88.

R\&I (Rating and Investment Information Inc.), 1998. Guide to Rating (in Japanese), Nihon Keizai Shinbun Inc.

Shin, Y. S., Moore, W. T., 2003. Explaining Credit Rating Difference between Japanese and U.S. Agencies. Review of Financial Economics 12, 327-44.

Ujiie, Junichi (ed.), 2002, Japanese financial markets, Cambridge, England : Woodhead.

Yamasawa, K., 2003. Practical Guide to Rating and the Rating Industry (in Japanese), Toyo Keizai Inc.

Yamori, N., Asai, Y., The Demise of Bank-centered Economy and Increasing Roles of Credit Ratings in Japan, in Lynde, V. R. (Eds.), International Banking Issues Retail Price, Nova Science Publishers (forthcoming). 
Figure 1. Recent Rising Funds of Non-financial Corporations: International Comparison

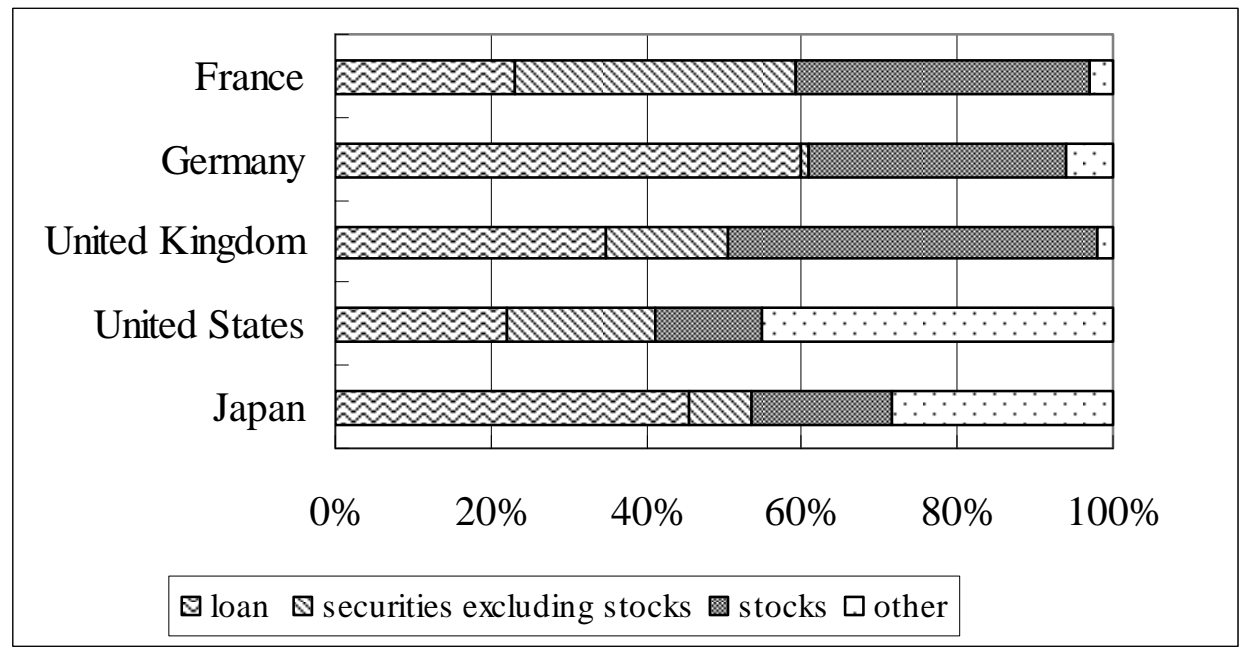

(Notes) (1) The data period is from 1997 to 2001.

(2) Figures are directly provided by the Bank of Japan. The Bank of Japan calculated these figures based on the Flow of Funds statistics of each country. (Bank of Japan, "International Comparison of the Flow of Funds statistics,” December 2003.)

Figure 2. Shares of Securities Excluding Stocks in Total Liability of Japanese Non-Financial Corporations

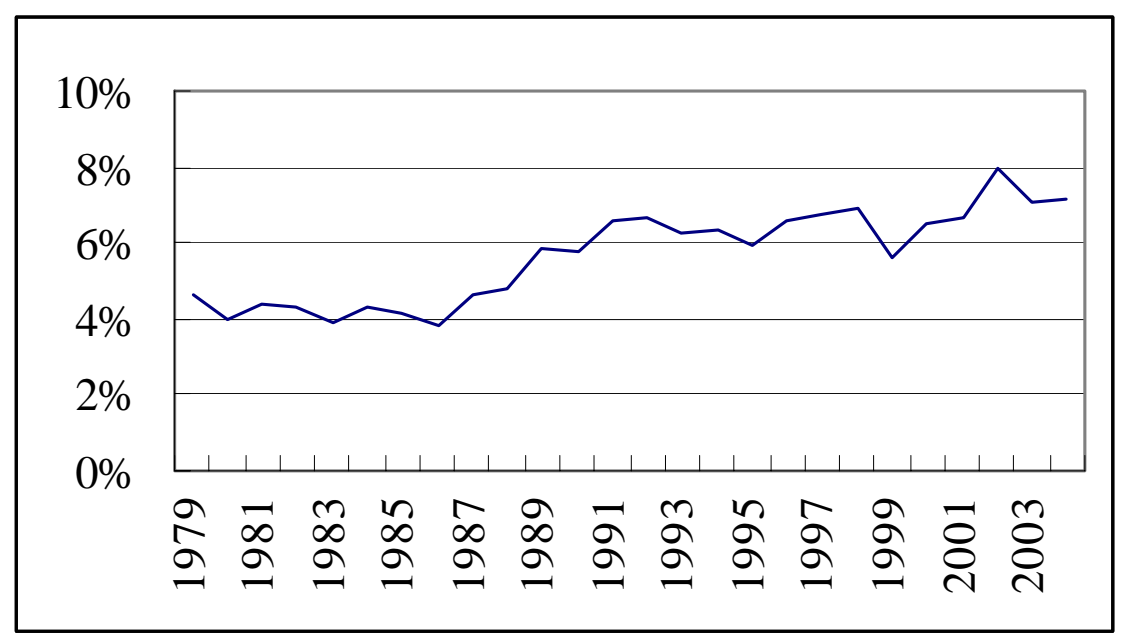

(Note) Bank of Japan, Flow of Funds (93SNA base), covering the period from 1979 to today. 
Table 1. Major Failures and Arrangement of Corporate Bonds

\begin{tabular}{|c|l|r|r|l|l|}
\hline & Company name & $\begin{array}{l}\text { Total } \\
\text { debts } \\
\text { (million } \\
\text { yen }\end{array}$ & $\begin{array}{l}\text { Collection } \\
\text { Rate } \%)\end{array}$ & $\begin{array}{l}\text { Category of } \\
\text { corporate bonds }\end{array}$ & $\begin{array}{l}\text { Arrangement of } \\
\text { corporate bonds }\end{array}$ \\
\hline Sep-96 & Olympics Sports & 35,506 & N.A. & $\begin{array}{l}\text { Publicly-issued CB } \\
\text { in Euros }\end{array}$ & N.A. \\
\hline Aug-97 & Daito Kogyo & 159,221 & 8 & $\begin{array}{l}\text { Privately-placed SB } \\
\text { in Swiss Francs }\end{array}$ & N.A. \\
\hline Sep-97 & Yaohan Japan & 161,383 & 3 & $\begin{array}{l}\text { Publicly-issued } \\
\text { domestic CB }\end{array}$ & $\begin{array}{l}\text { Purchase of CB at 10\% } \\
\text { of face values }\end{array}$ \\
\hline Oct-98 & Morisho & 16,121 & N.A. & $\begin{array}{l}\text { Privately-placed CB } \\
\text { in Swiss Francs }\end{array}$ & $\begin{array}{l}\text { Paid full values by } \\
\text { using collaterals. }\end{array}$ \\
\hline $\begin{array}{c}\text { Oct-98 } \\
\text { Tescon }\end{array}$ & JDC & 406,717 & $\begin{array}{l}\text { Privately-placed CB } \\
\text { in Euros }\end{array}$ & N.A. \\
\hline $\begin{array}{c}\text { Dec- } \\
\text { Sep-01 }\end{array}$ & Mycal & $1,388,000$ & N.A. & $\begin{array}{l}\text { Publicly-issued } \\
\text { domestic SB and } \\
\text { others }\end{array}$ & $\begin{array}{l}10 \% \text { of face values in } \\
\text { the case of an } 19 \text { year } \\
\text { installment plan }\end{array}$ \\
\hline
\end{tabular}

(Notes)(1) CB=convertible bonds, SB=straight bonds.

(2) The authors drew up the table based on Ujiie (2002) and the Institute for Posts and Telecommunications Policy of the Ministry of Internal Affairs and Communications (2003).

Figure 3. Development of Japanese Straight Bond Markets

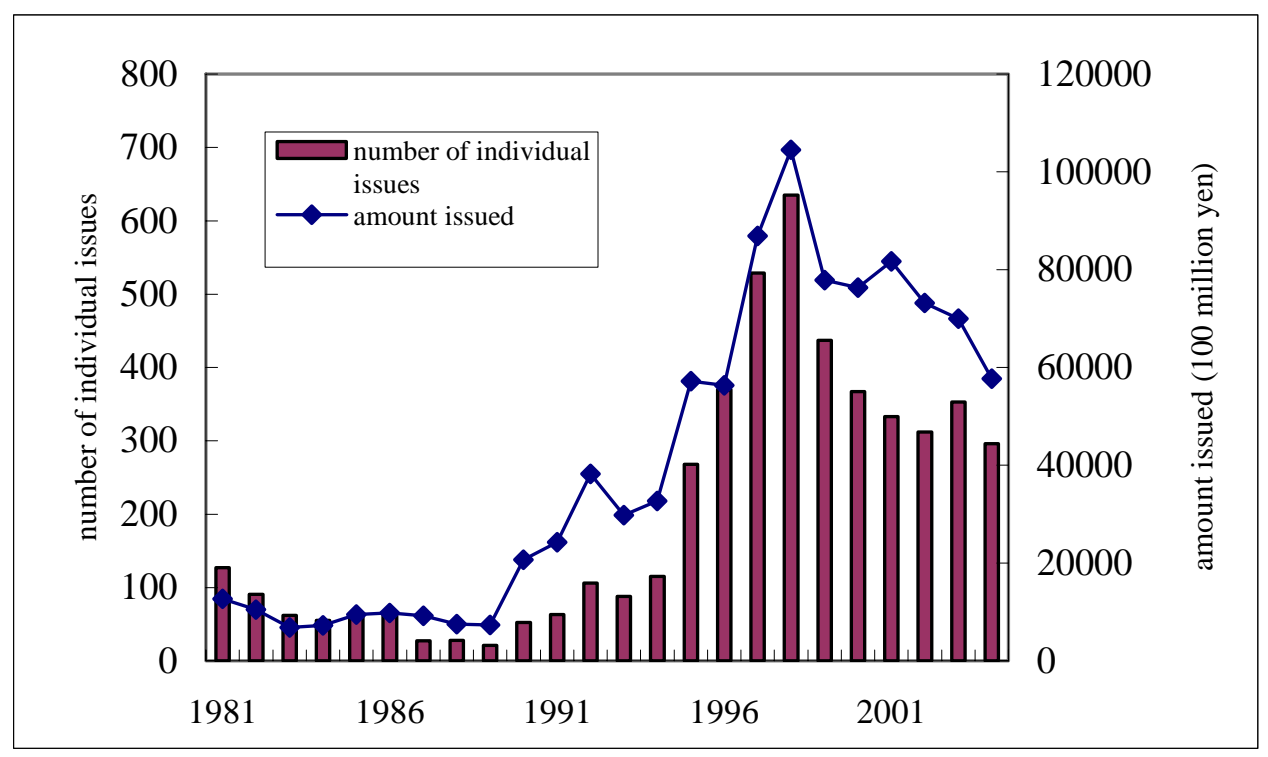

(Source) Ministry of Finance, Zaimusho Kinyu Tokei Geppou (Domestic Economy). 
Figure 4. Bonds Issuing by Issuers

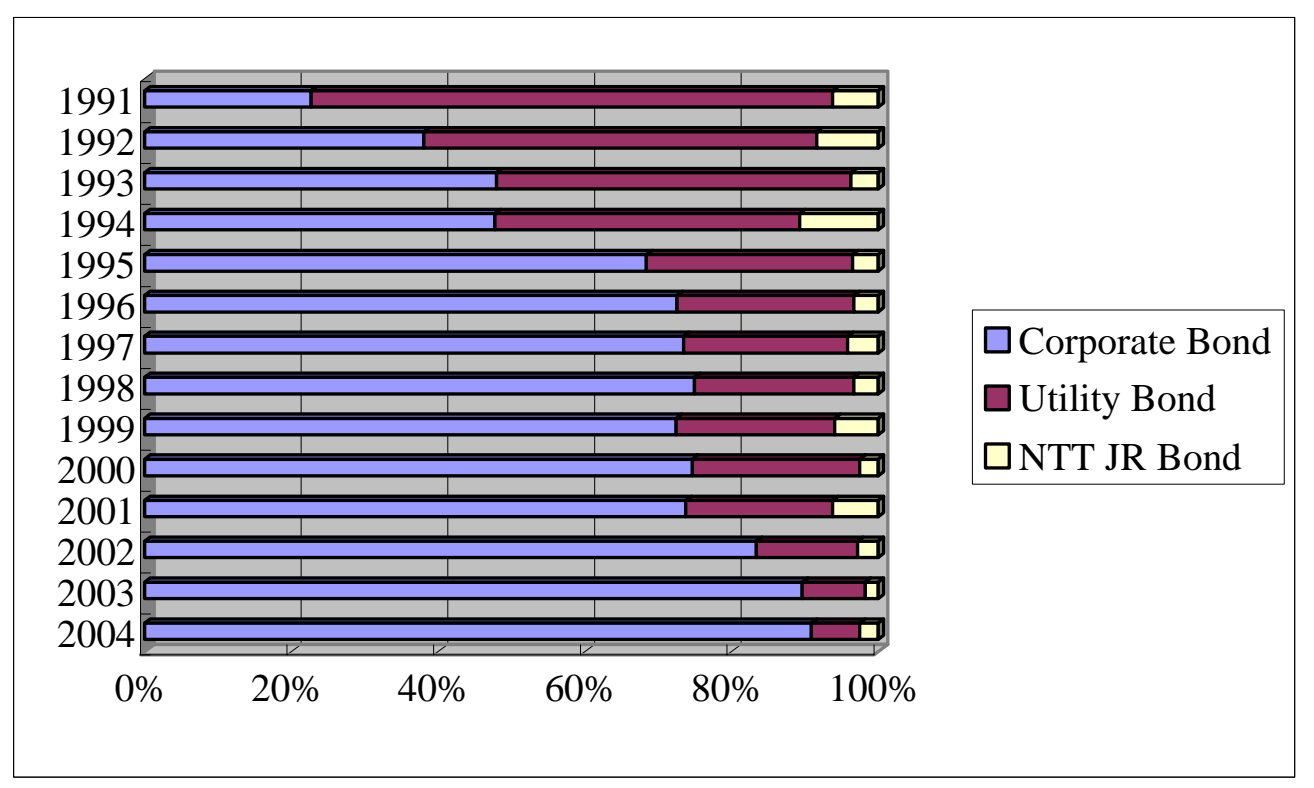

(Note) NTT is Nippon Telegraph and Telephone Corporation, and JR is Japan Railways. Both of them used to be state-owned firms.

(Source) Ministry of Finance, Zaisei Kinyu Tokei Geppou.

Table 2. Number of Raters

\begin{tabular}{|c|c|c|r|c|}
\cline { 2 - 5 } \multicolumn{1}{c|}{} & 1993 & 1996 & 2000 & 2004 \\
\hline 1 rater & 54 & 144 & 189 & 165 \\
\hline 2 raters & 24 & 190 & 104 & 100 \\
\hline 3 raters & 6 & 22 & 46 & 27 \\
\hline 4 raters & 4 & 7 & 11 & 5 \\
\hline Total & 88 & 363 & 350 & 297 \\
\hline
\end{tabular}

Table 3. Which Rating Company Did Firms Choose?

\begin{tabular}{|c|c|c|c|c|c|}
\hline \multirow{2}{*}{ Rating } & \multicolumn{2}{|c|}{ R\&I } & \multirow{2}{*}{ Moody's } & S\&P & JCR \\
\cline { 2 - 3 } & JBRI & NIS & & & \\
\hline 1993 & 56 & 32 & 30 & 8 & 10 \\
\hline 1996 & 182 & 117 & 188 & 30 & 101 \\
\hline 2000 & 250 & 72 & 67 & 190 \\
\hline 2004 & 218 & 50 & 28 & 170 \\
\hline
\end{tabular}


Table 4. Combinations of Raters for 1993 and 1996

\begin{tabular}{|l|l|l|l|l|l|l|l|l|l|l|}
\hline & $\begin{array}{l}\text { JBRI } \\
\text { NIS }\end{array}$ & $\begin{array}{l}\text { JBRI } \\
\text { MDY }\end{array}$ & $\begin{array}{l}\text { JBRI } \\
\text { S\&P }\end{array}$ & $\begin{array}{l}\text { JBRI } \\
\text { JCR }\end{array}$ & $\begin{array}{l}\text { NIS } \\
\text { MDY }\end{array}$ & $\begin{array}{l}\text { NIS } \\
\text { S\&P }\end{array}$ & $\begin{array}{l}\text { NIS } \\
\text { JCR }\end{array}$ & $\begin{array}{l}\text { MDY } \\
\text { S\&P }\end{array}$ & $\begin{array}{l}\text { MDY } \\
\text { JCR }\end{array}$ & $\begin{array}{l}\text { S\&P } \\
\text { JCR }\end{array}$ \\
\hline 1993 & 12 & 22 & 7 & 0 & 13 & 4 & 0 & 8 & 0 & 0 \\
\hline 1996 & 21 & 103 & 24 & 14 & 80 & 9 & 3 & 11 & 30 & 3 \\
\hline
\end{tabular}

Table 5. Combinations of Raters for 2000 and 2004

\begin{tabular}{|l|l|l|l|l|l|l|}
\hline & R\&I & R\&I & R\&I & MDY & S\&P & MDY \\
MDY & S\&P & JCR & S\&P & JCR & JCR \\
\hline 2000 & 47 & 46 & 99 & 54 & 35 & 27 \\
\hline 2004 & 39 & 19 & 96 & 23 & 22 & 12 \\
\hline
\end{tabular}

Table 6. Combinations of Rating Agencies

\begin{tabular}{|l|l|l|l|}
\hline & $\begin{array}{c}\text { Both Japanese } \\
\text { rating } \\
\text { companies }\end{array}$ & $\begin{array}{c}\text { Japanese and U.S. } \\
\text { rating companies }\end{array}$ & $\begin{array}{c}\text { Both U.S. } \\
\text { rating } \\
\text { companies }\end{array}$ \\
\hline 1993 & 12 & 46 & 8 \\
\hline 1996 & 24 & 263 & 11 \\
\hline 2000 & 99 & 155 & 54 \\
\hline 2004 & 96 & 92 & 23 \\
\hline
\end{tabular}

Table 7. Relationship between the Number of Ratings, Amount of Bonds Issued, and

Maturity and Interest Rates in 2004

\begin{tabular}{|l|c|c|c|}
\hline Amount of issue & 1 rating & 2 ratings & 3 ratings \\
\hline Not over 100 million & 90 & 54 & 8 \\
\hline 100 -200 million & 21 & 8 & 1 \\
\hline 200 million and above & 56 & 38 & 19 \\
\hline Average (million yen) & 169.42 & 192.81 & 204.17 \\
\hline Median (million yen) & 100 & 100 & 125 \\
\hline Maturity & & & \\
\hline Not over 5 years & 78 & 42 & 9 \\
\hline $5-10$ years & 38 & 19 & 1 \\
\hline 10 years and above & 51 & 39 & 17 \\
\hline Average (years) & 7.29 & 8.99 & 8.17 \\
\hline Median (years) & 6 & 10 & 10 \\
\hline Interest rate & & & \\
\hline Not over 0.75\% & 21 & 17 & 6 \\
\hline $0.75-1.5 \%$ & 79 & 38 & 6 \\
\hline $1.5 \%$ and above & 50 & 34 & 14 \\
\hline Average (\%) & 1.31 & 1.48 & 1.29 \\
\hline Median (\%) & 1.29 & 1.55 & 1.29 \\
\hline
\end{tabular}

(Note) The figures in the rows except Average and Median depict the number of issues that fall under the category. 
Table 8. Simple Average of Ratings by Raters

\begin{tabular}{|l|l|l|l|l|l|}
\hline \multirow{2}{*}{ Rating } & \multicolumn{2}{|c|}{ R\&I } & MDY & S\&P & JCR \\
\cline { 2 - 3 } & \multicolumn{2}{|c|}{ JBRI } & NIS & & \\
\hline 1993 & 2.70 & 2.31 & 5.19 & 1.88 & 6.13 \\
\hline 1996 & 4.22 & 4.49 & 7.46 & 4.87 & 6.19 \\
\hline 2000 & 4.54 & 5.03 & 5.42 & 4.84 \\
\hline 2004 & 5.40 & 5.43 & 5.31 & 5.23 \\
\hline
\end{tabular}

(Note) JBRI and NIS merged into R\&I in 1998.

Table 9. Average Ratings for Overlapped Firms

\begin{tabular}{|c|c|c|c|c|c|c|c|c|c|c|c|c|}
\hline & JBRI & NIS & JBRI & MDY & JBRI & S\&P & JBRI & JCR & NIS & MDY & NIS & S\&P \\
\hline 1993 & 2.000 & 1.667 & 2.545 & 4.727 & 1.286 & 2.000 & N/A & N/A & 1.923 & 4.692 & 1.000 & 1.250 \\
\hline \multirow[t]{2}{*}{1996} & 3.800 & 3.600 & 3.653 & 6.535 & 2.500 & 4.125 & 4.929 & 6.643 & 3.823 & 7.329 & 2.000 & 4.333 \\
\hline & NIS & JCR & M D Y & S\&P & M D Y & JCR & S\&P & $\mathrm{JCR}$ & & & & \\
\hline 1993 & N/A & N/A & 1.750 & 1.875 & N/A & N/A & N/A & N/A & & & & \\
\hline 1996 & 6.000 & 10.000 & 2.364 & 4.818 & 9.600 & 5.033 & 10.667 & 6.000 & & & & \\
\hline
\end{tabular}

\begin{tabular}{|l|ll|ll|ll|ll|ll|ll|}
\hline & R\&I & MDY & R\&I & S\&P & R\&I & JCR & MDY & S\&P & S\&P & JCR & MDY & JCR \\
\hline 2000 & 4.361 & 3.588 & 2.565 & 4.978 & 4.361 & 3.588 & 5.000 & 5.760 & 4.795 & 1.846 & 5.087 & 1.565 \\
\hline 2004 & 3.471 & 5.824 & 3.286 & 5.500 & 5.473 & 4.516 & 4.727 & 5.409 & 6.167 & 2.417 & 5.300 & 2.100 \\
\hline
\end{tabular}

Figure 5. Difference in Interest Rates for the Same Credit Ratings among Raters

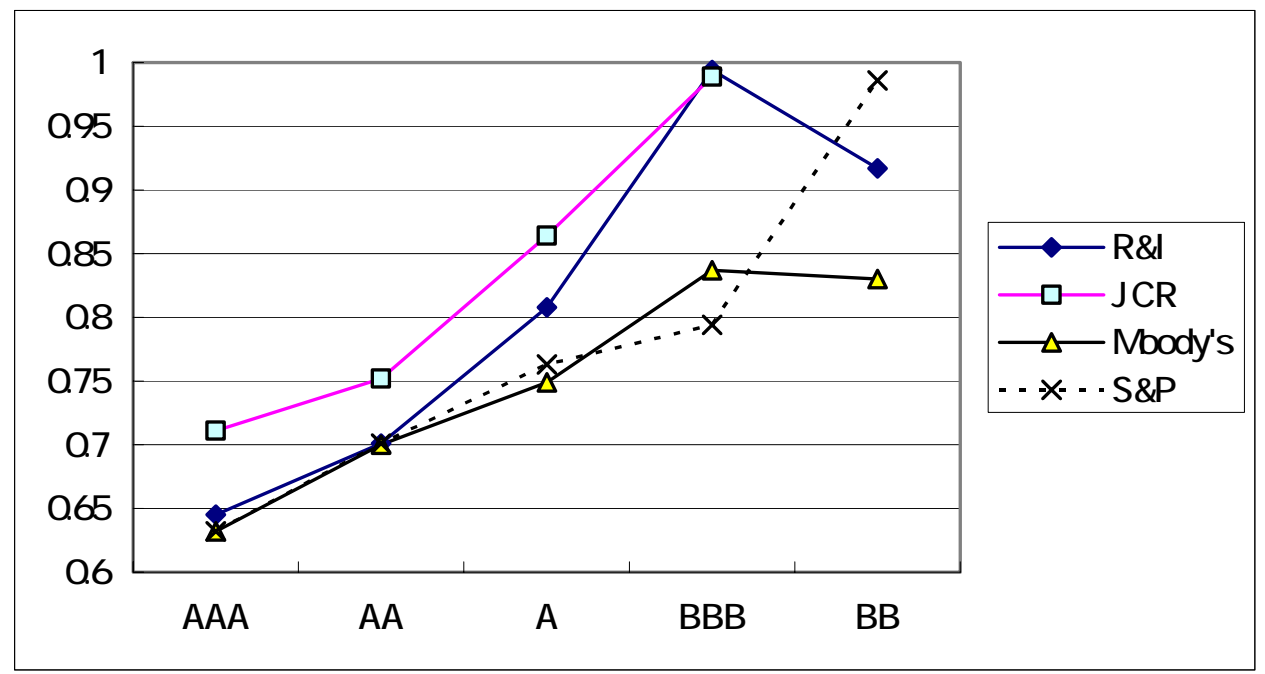


Table 10 (a) Simple correlation coefficient in 1993

\begin{tabular}{|l|r|r|r|r|r|}
\hline & \multicolumn{1}{|l|}{ JBRI } & \multicolumn{1}{l|}{ NIS } & MDY & S\&P & JCR \\
\hline JBRI & 1.000 & & & & \\
\hline NIS & 0.934 & 1.000 & & & \\
\hline MDY & 0.972 & 0.673 & 1.000 & & \\
\hline S\&P & 0.441 & N/A & 0.701 & 1.000 & \\
\hline JCR & N/A & N/A & N/A & N/A & 1.0000 \\
\hline
\end{tabular}

Table 10 (b) Simple correlation coefficient in 1996

\begin{tabular}{|l|r|r|r|r|r|}
\hline & JBRI & \multicolumn{1}{l|}{ NIS } & MDY & \multicolumn{1}{l|}{ S\&P } & JCR \\
\hline JBRI & 1.000 & & & & \\
\hline NIS & 0.986 & 1.000 & & & \\
\hline MDY & 0.877 & 0.755 & 1.000 & & \\
\hline S\&P & 0.912 & N/A & 0.718 & 1.000 & \\
\hline JCR & 0.494 & N/A & 0.691 & N/A & 1.000 \\
\hline
\end{tabular}

Table 10 (c) Simple correlation coefficient in 2000

\begin{tabular}{|l|l|l|l|l|}
\hline & R\&I & MDY & S\&P & JCR \\
\hline R\&I & 1.000 & & & \\
\hline MDY & 0.906 & 1.000 & & \\
\hline S\&P & 0.798 & 0.644 & 1.000 & \\
\hline JCR & 0.936 & 0.785 & 0.959 & 1.000 \\
\hline
\end{tabular}

Table 10 (d) Simple correlation coefficient in 2004

\begin{tabular}{|l|l|l|l|l|}
\hline & R\&I & MDY & S\&P & JCR \\
\hline R\&I & 1.000 & & & \\
\hline MDY & 0.912 & 1.000 & & \\
\hline S\&P & 0.884 & 0.964 & 1.000 & \\
\hline JCR & 0.961 & 0.783 & 0.874 & 1.000 \\
\hline
\end{tabular}

